\title{
Research on the ideological and political construction of macroeconomics course under the background of high quality development of Higher Education
}

\author{
$\mathrm{He} \mathrm{JIANG}^{1, \mathrm{a}}$,Yonghui $\mathrm{CAO}^{* 2, \mathrm{~b}}$ \\ ${ }^{1}$ Department of Business Administration Guangzhou College of Technology and Business Guangzhou, China \\ ${ }^{2}$ Department of Business Administration Guangzhou College of Technology and Business Guangzhou, China
}

\begin{abstract}
In the teaching of macroeconomics, we should strengthen the curriculum-based ideological and political education. This paper first introduces the necessity of Ideological and political education in macroeconomics; then it analyzes the common problems in curriculum-based ideological and political education of macroeconomics; finally, the paper explores from the concept of curriculum-based ideological and political education, the construction of teachers' Ideological and political ability and the scientific design the system of curriculum-based ideological and political education in macroeconomics, so as to realize the effect of the coordinated development of the curriculum-based ideological and political education and macroeconomics, so as to help students establish the correct world view, sense of worth, philosophy and cultivate the applied business management talents with a sense of mission and responsibility.
\end{abstract}

\section{Introduction}

In the new era, the leaders of the party and the state attach great importance to the education mode of higher education, and always emphasize the curriculum-based ideological and political education. General Secretary Xi pointed out: "to make good use of the main channel of classroom teaching, ideological and political theory courses should be strengthened in the process of improvement, enhance the affinity and pertinence of ideological and political education, and meet the needs and expectations of students' growth and development. All other courses should observe a certain channel and form a good responsibility field, so that all kinds of courses and ideological and political theory courses can work together to form a synergy effect." On June 1, 2020, the Ministry of Education issued the guiding outline for the ideological and political construction of higher education curriculum to comprehensively promote the ideological and political construction of higher education curriculum.

However, how to break the "island effect" of long-term isolation between Ideological and political education and professional education, and promote the coordinated development of curriculum ideological \& political education and professional education which is one of the important tasks facing Chinese colleges and Universities in the new era.

In March 2021, this paper searched CNKI with the keywords of "Curriculum Ideology and politics" and "macroeconomics", and only eight articles were retrieved, which were distributed from 2018 to 2021, indicating that this is also the current research hotspot.

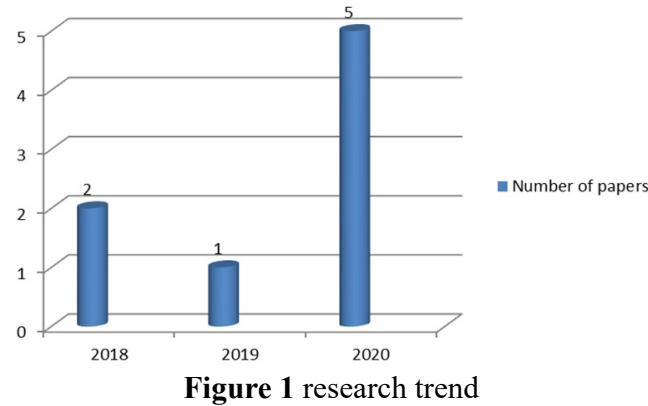

This paper will explore the ideological and political construction in the teaching process of macroeconomics, in order to improve students' ability to analyze and solve problems, cultivate students' patriotic feelings, and establish a correct world view, sense of worth, philosophy

\section{The necessity of curriculum-based ideological and political education into macroeconomics}

Macroeconomics is a core compulsory course for business administration majors, which is a theoretical, professional, practical and comprehensive course. The course mainly focuses on the determination of national income, and introduces a variety of macroeconomic phenomena such as unemployment, inflation, economic growth and corresponding policies. Through the study of macroeconomics, we can effectively cultivate students' economic thinking, help students understand the current situation of macroeconomic development in various countries and interpret the relevant macro emergency 
policies, so as to make students have the consciousness of innovation and transformation.

Macroeconomics is an important part of western economics, and its ideology cannot be ignored. The emergence and development of western economics is rooted in the capitalist society. Although it is scientific in explaining the economic operation law and related economic policies of capitalist society, western economics essentially serves the bourgeoisie and has a distinct class nature. Therefore, in the teaching process of western economics, we should recognize and always remember the essential attribute of bourgeois "ideology" of western economics.

The teaching of macroeconomics should be combined with China's macroeconomic situation. While teaching the basic principles of western macroeconomics, we need to systematically use the theory of socialism with Chinese characteristics guided by Marxism to analyze and explain the road and successful experience of contemporary China's economic development, so as to enhance the students' ability to correctly analyze the internal logic of China's economic development by using macroeconomic theory under the guidance of Marxism. Therefore, the construction of ideological and political education should run through the whole process of macroeconomics, and actively explore the trinity of knowledge teaching, value guidance and ability training of macroeconomics, so as to realize the goal of all staff, whole process and all-round education of higher education.

\section{Problems in curriculum-based ideological and political education in Macroeconomics}

\section{1 there is a cognition deviation in the curriculum-based ideological and political education}

Curriculum-based ideological and political education refers to a comprehensive education concept which constructs the whole staff, the whole process and the whole curriculum education pattern, makes all kinds of courses and ideological and political theory courses in the same direction, forms a synergistic effect, and takes "moral cultivation" as the fundamental task of education. In the teaching practice, there are some deviations in the cognition of Ideological and political education, which are mainly manifested in the following aspects: first, Lack of in-depth understanding of curriculum-based ideological and political education: teachers sort out the elements or resources of Ideological and political education in macroeconomics, and teachers focus on explaining this part of the content in the classroom, so that macroeconomics becomes an ideological and political course, which disrupts the design of key and difficult points in the syllabus and affects the normal order of education; the second is formalization of curriculumbased ideological and political education: some colleges and universities have set up their own so-called "brand" courses, while other schools have imitated and copied their practice in the form of curriculum, which leads to the form is greater than the content, the teaching effect is not satisfactory, and a lot of human and material resources are wasted; the third is the utilitarianism of curriculumbased ideological and political education: many colleges and universities set aside special funds or set up special teaching and research projects to ensure the smooth progress of curriculum ideological and political education, but participate in the practice of "curriculum ideological and political education" in order to obtain special funds or teaching and research projects, resulting in the lack of Ideological and political education.

\section{2 the ability of curriculum-based ideological and political education construction of macroeconomics teachers is insufficient}

Most macroeconomics teachers graduated from business administration majors, and their professional knowledge of Ideological and political education is lack of systematicness, especially for some young teachers. Macroeconomics is a course of partial theory and mathematical logic reasoning. In the existing teaching process, teachers generally pay more attention to the construction, deduction and application of models in macroeconomics, and the related concepts, theories and policies involved are mostly from the research of capitalist countries. In the process of teaching, the teaching concept focuses more on the imparting of knowledge, or criticizing western economic theories according to the text, which is lack of maturity ideological and political thought of the curriculum.

\subsection{It has not yet formed a perfect curriculum- based ideological and political education system in macroeconomic}

The construction of curriculum-based ideological and political education in macroeconomics is still in the exploratory stage, and the perfect teaching system has not yet been formed. In terms of teaching materials, although most schools choose Ma engineering teaching materials from higher education press, the ideological and political content of most teaching materials only stays on the criticism of western economic theory, which will cause some confusion to students in the learning process. In terms of teaching design, macroeconomics is a course with perfect logical structure. There is still no mature solution to the problem of how to increase the ideological and political content of the course on the basis of its rigorous logical structure without destroying its original logical structure. In terms of teaching content, macroeconomics, as a professional basic course, is theoretical and boring for students. In teaching practice, if teachers do not dig deep enough or explain clearly enough, the teaching effect will be greatly reduced. In terms of teaching effect evaluation, the assessment of macroeconomics adopts the way of usual results plus final examination. The usual results are measured by attendance rate, homework completion and other aspects. The final examination is still based on students' mastery of knowledge points, while the 
assessment of Ideological and political aspects of the course is less, which makes students mistakenly think that the ideological and political contents of the course are not included in the assessment, which will reduce the emphasis on the ideological and political content of the course.

\section{The realization path of curriculum- based ideological and political education reform in macroeconomics}

\subsection{Establish a correct teaching concept of curriculum-based ideological and political education}

Comprehensively promoting curriculum-based ideological and political education is a strategic measure to implement the fundamental task of moral education. The goal of curriculum-based ideological and political education is to integrate values into knowledge teaching and ability training, and help students shape correct world outlook, outlook on life and values. As a basic course of Business Administration major, the integration of ideological and political education into the teaching of macroeconomics could help students closely combining the course of China's macroeconomic development with the decisive role of the Communist Party of China in promoting China's macroeconomic development, thinking about the driving force and source of China's economic development and the contribution of individual students to the future economic development, mastering the basic research methods of macroeconomic theory, analyze and evaluate macroeconomic phenomena. The construction of curriculum-based ideological and political education in macroeconomics needs to be like salt in water, As General Secretary Xi pointed out, good ideological and political work should be like salt, but not salt eating, the best way is to dissolve the salt into all kinds of food and naturally absorb it. In the construction of curriculum-based ideological and political education in macroeconomics, teachers should let students be influenced by their own ideals and beliefs, moral sentiment, solid knowledge and benevolence through their own words and deeds. The construction of curriculum-based ideological and political education in macroeconomics should be in line with its own curriculum characteristics to construct an effective path to carry out the course Ideological and political construction, that is, to organically integrate the ideological and political elements, so that the elements of value guidance in curriculum design and classroom teaching are like salt in water, so as to achieve the educational effect of "spring breeze turns rain, moistening things silently".

\section{2 improve the curriculum-based ideological and political education construction ability of macroeconomics teachers}

The ways to improve the ability of curriculum-based ideological and political education of macroeconomics teachers mainly include the following points: The first is to improve the ideological and political theory literacy of macroeconomics teachers: by integrating the ideological and political curriculum into the pre job training, on-thejob training, professional ethics and teaching ability training, teachers' Ideological and political theory knowledge can be continuously supplemented to improve their ideological and political literacy. The second is to enhance the enthusiasm and initiative of macroeconomics teachers to participate in the curriculum-based ideological and political education. By establishing and improving the sharing mechanism of high-quality resources of macroeconomics curriculum, we can promote the sharing of high-quality resources among different regions, levels and types of universities, and establish communication platforms and mechanisms between different universities, so as to enhance the enthusiasm and initiative of teachers to participate in the ideological and political construction of the curriculum. The third is to establish the collective teaching and research system of curriculum-based ideological and political education. In view of the key, difficult and forward-looking problems in the construction of Ideological and political education, we can put forward corresponding solutions through collective teaching and research and discussion among teaching teams, and sort out the key points of Ideological and Political Education to make it systematic.

\section{3 design a scientific ideological and political teaching system in macroeconomics}

To design a scientific ideological and political teaching system in macroeconomics, that is to say, to integrate the ideological and political education into the teaching process of macroeconomics. The content of Ideological and political construction of macroeconomics course should focus on Strengthening Students' ideals and beliefs, take loving the party, patriotism, socialism, people and collective as the main line, and optimize the supply of Ideological and political content of the course focusing on political identity, national feelings, cultural quality and moral cultivation, combined with the important events in the process of building socialism with Chinese characteristics and the education of Chinese dream, the education of socialist core values and the education of Chinese excellent traditional culture. Specifically speaking, the construction of curriculum-based ideological and political education in macroeconomics should be implemented in all aspects of curriculum teaching and run through all aspects of personnel training; by improving the classroom teaching management system and innovating the classroom teaching mode, we should strive to expand the methods and ways of Ideological and political construction of the curriculum.

(1) Integrating Ideological and political elements into the whole process of macroeconomics

The difficulty of the integration of Ideological \& political elements and teaching design is how to make students master the theory of macroeconomics in an easy to understand way. At the same time, the ideological and political thought is infiltrated into the course teaching to 
achieve the effect of teaching and educating people. For example, when it comes to GDP, through the vertical comparison of China's GDP data over the past 40 years, it affirms the great achievements of China's economic construction since the reform and opening up, guides students to establish a strong sense of national pride and self-confidence, and enhances students' patriotic feelings. Through the horizontal comparison of GDP and per capita GDP between European and American countries and China in recent two years, students can understand that there is still a gap between China and developed countries. In order to realize China's economic status as a big country, college students need to work hard to encourage students to study hard and make contributions to the prosperity of the country.

If the idea of Ideological and political education runs through the whole macroeconomics course, we must reasonably design and arrange the teaching content. When writing syllabus, lesson plans, lecture notes and courseware, we should infiltrate new socialist thoughts with China characteristics into the teaching contents of each chapter, give the curriculum's "moral education function" and "Ideological and political ability", and cultivate students' correct outlook on life, values and world outlook. In the specific design of classroom teaching, we should integrate the new development concept of innovation, coordination, green, open and sharing, cultivate and practice the socialist core values and other ideological and political elements into classroom teaching.

(2) Innovate the ideological and political classroom teaching mode in Macroeconomics

In the construction of curriculum-based ideological and political education in macroeconomics, it combined teachers' explanation, video case introduction, students' group discussion, individual exchange speech and online second classroom learning. Before class: the teacher arrange preview content, provide course exercises, and arrange some data collection related to macroeconomic theory in China. Students refine core content and problems through autonomous learning in preview stage. In class: we suggest adopt the problem-based teaching method, and answers the key points and difficulties of knowledge in detail. It introduces the case based on China's national conditions -- specific theory, combined with textbook cases and Chinese cases, situational teaching - using modern teaching facilities such as video, multimedia and so on. It pays attention to the thoroughness of content explanation, and fully infiltrates the socialist values and students' moral elements It can guide students' interest in the course of economic theory, stimulate students' learning enthusiasm, and constantly accumulate knowledge and ability. After class: on the basis of the original exercise set, the teachers add the ideological and political problems of the course, urge the students to find materials and discuss the follow-up courses, and strengthen the students' second classroom learning. With modern teaching methods to show the elements of "Ideological and political course", we make full use of modern multimedia teaching methods, and deeply integrate some audio-visual, pictures and web pages that can fully reflect the spirit of the 19th National Congress of the Communist Party of China and the moral education elements in the socialist core values into our teaching courseware, and infiltrate into the teaching process of macroeconomics course from multiple angles. For example, when teaching the macroeconomic policy objectives of economic growth, full employment, price stability, we show the images and videos of the national mainstream media reports on these related issues to students, so that students can have a deep understanding of the major achievements of China's economic construction. In this way, students' understanding and recognition of the concepts of "road confidence, theoretical confidence, system confidence and cultural confidence" are deepened.

\section{Conclusion}

The construction path of Ideological and political education in macroeconomics is to realize the Trinity Teaching Mode of "knowledge imparting", "value leading" and "ability training". This paper analyzes the necessity and common problems of Ideological and political education in macroeconomics, this paper explores the construction path of the ideological and political education in macroeconomics from the following aspects: establishing the correct ideological and political concept of macroeconomics curriculum, the construction of teachers' Ideological and political ability, and the scientific design of the teaching system of macroeconomics. In order to achieve the effect of the coordinated development of Ideological \& political education and macroeconomics, so as to help students establish a correct "Three Outlooks", it is conducive to the cultivation of applied business management talents with a sense of mission and responsibility.

\section{Acknowledgment}

This work is financially supported by "Four one" construction pilot project of Ideological and political course of Guangzhou College of Technology and Business in 2020(KCSZ202001); outstanding scholars of philosophy and Social Sciences in Henan Province higher education in 2018, 2018-YXXZ-06; Henan philosophy and Social Sciences Planning Project in 2019, 2019BJJ003; The social development project of Henan provincial key R \& D and promotion project (Science and technology tackling key problems) in 2019, project number: 515; Intellectual property soft science research project of Henan Province in 2021, 20210106014; Guangdong Education Science Planning Project, building an efficient and intelligent supply chain system to promote the high-quality economic development of GuangdongHong Kong-Macao Greater Bay Area, 2019GXJK072; Henan philosophy and Social Sciences Planning Project in 2019, 2019BJJ032; Key scientific and technological projects of Henan Province in 2021, 212102310051, Research on emergency decision-making mechanism and key technologies of major public emergencies; the key scientific research project of colleges and universities in Henan Province in 2021, 21A620002; General Topics of Henan Province Educational Science "13th Five-Year 
Plan" in 2020, Research on the dynamic mechanism of the integration of industry and education in Henan Province, 2020YB0146; Guangdong higher education reform project in 2020, No. 642, innovative research and practice of logistics personnel training mode based on new information technology under the background of new business. The project of quality engineering of Guangzhou College of Technology and Business in 2020, serial number 25, the exploration of the dynamic mechanism and path of the integration of production and education of undergraduate colleges in Guangdong-Hong Kong-Macao Greater Bay Area. Thanks for the help.

\section{References}

1. He Wuhua, Wang lingdun. Review and Prospect of curriculum ideological and political research in China [J]. School party construction and ideological education, 2021 (04): 26-30

2. Wang Ying, sun qi'ang. The political foundation of Ideological and political teachers in university curriculum: theoretical interpretation and deep cultivation path $[\mathrm{J} / \mathrm{OL}]$. University education management, 2021 (02): 1-10 [2021-02-28]

3. Zhang Daliang. Curriculum, ideology and Politics: the fundamental principle of moral education in the new era $[\mathrm{J}]$. China higher education research, 2021 (01): 5-9

4. Wang Xinhua, Wang Na. On the value guidance of curriculum ideological and political reform [J]. School party construction and ideological education, 2021 (02): 52-54

5. Fu Yong Xiang. "Internet plus" Ideological and political education helps foster [J]. youth forum for new era youth, 2021 (01): 94-96.

6. Fan Liming. Four key issues in the ideological and political construction of finance courses [J]. China higher education research, 2020 (09): 4-8

7. Jin Weiping. Preliminary practice of Ideological and political education in the course of principles of Economics [J]. Teaching in Chinese universities, 2020 (z1): 54-59

8. Liu Jianhong. Teacher training in Colleges and Universities: the viewpoint of demand side and its suggestions [J]. Research on higher normal education, 2002, 14 (6): 58-62 